\title{
COMPARATIVE ENVIRONMENTAL GOVERNANCE, LAW AND POLICY: AN ANALYSIS OF JUDICIAL TECHNIOQUES IN INDIA AND NIGERIA
}

\begin{abstract}
The judiciary is a crucial partner in the development, interpretation, implementation, and enforcement of environmental law and policy - particularly, the development and actualization of the broad national goals of environmental governance and sustainable development through balancing environmental, social, economic and developmental choices in its judicial decision making process in both Nigeria and India.

This paper reviews the techniques employed by the Courts in selected cases in their decision making process aimed at maintaining their countries commitment to the sensitivity of the environment and the need to deepen environmental governance in an era of climate peril.
\end{abstract}

\section{Keywords}

environment - environmental governance - sustainable development - judicial decision making - constitutional interpretation - judicial activism - human rights - international environmental law and policy

* Prof. Orubebe Bibobra Bello, F.A.I.R, LL.B (Hons), BL, LL.M and Doctor of Juridical Science (SJD), Professor of Law, Provost/Dean College of Law, Novena University Ogume, Delta State Nigeria, bborubebe@gmail.com 


\section{INTRODUCTION}

Nigeria and India are the most populous countries and indeed democracies in Africa and Asia. Both countries have many ethnic groups and enjoy diverse climate features which include mountains, deserts, coastal, riverine, and wetlands with seasonal weather. Politically, Nigeria ${ }^{1}$ and India ${ }^{2}$ were both British colonies and are endowed with huge human and natural resources. As a heritage of colonialism the countries inherited dubious trust-styled legal and institutional arrangements that disinherited most of their local populations particularly, environmental, political, social, economic (property / land / resources), and cultural rights. These and other identifiable contradictions have exacerbated the current environmental cum development crisis in both countries. The lack of cocoordinated regulatory environmental and developmental institutional framework, has had serious repercussions on the environment. In prehistorical times, both India and Nigeria were at the heart of intra and inter-tribal trade, and human civilization. These peculiar commonalities in environmental governance history enabled both countries to act and interact with countless other cultures, contributing to the evolution of the global human success story as we know it today. They both share a unique history and indeed practice of acting with and leading others to address the issues of poor environmental governance over the years.

\section{Conceptual Framework and Operational DEFINITION OF KEY TERMS}

In consideration of the jurisprudential meaning of the concept of environmental governance one must note that there are some key words whose meaning is to be ascertained from the beginning for better appreciation as well as the understanding of the theme of the paper. The words are "environmental governance", "Judicial Activism", "Fundamental Human Rights Abuse" and "Sustainable Development".

\footnotetext{
${ }^{1}$ Nigeria gained political independence from Great Britain on $1^{\text {st }}$ October 1960.

${ }^{2}$ India obtained political independence from Great Britain on 15 August 1947.
} 
"Fundamental Human Rights Abuse" is used in this work to denote a misuse of both political as well as administrative power against some members of the Indian and Nigerian citizenry under the pretence of economic development. It also connotes the unconstitutional as well as illegal actions taken by both countries executives and some corporations under the pretence of industrial or economic development without respecting the rights under both nations' constitutions and other international treaties that have to do with rights (including environmental, pollution free, sustainable development, safe environment, etc.). "Environmental governance" means different things to policy makers, researchers, students, organizations, academics, etc. However, notwithstanding these divergences of approach, in this paper environmental governance refers to the synergy of identifiable characteristics notably- predictable, clear, implementable environmental laws and policies, developed with the active participation of the citizenry that hold violators accountable and afford citizens unfettered access of enforcement through the Courts. "Sustainable development" is development coupled with authority to compel adherence to sustainable norms or rules which ensure that society meets the needs of the present without compromising the ability of future generations to meet their own needs. " "Judicial activism" means the interpretational ability of the judiciary to go beyond the mere or ordinary strict application of law and policy to the facts of each case and are necessary to seek reliance on equity and impose their own values and policy preferences to remedy otherwise hopeless situations, in the Courts 'interpretational' development and judicial enactment of Constitutional Law, international treaties, policy and principles. "Environmental rights" put simply is an amalgam of all the instrumental human rights that pertain to all human beings at all times and form the fulcrum of the basis or justification for the enjoyment of all other rights howsoever described.

In the past, in an attempt to respond to the rapidly deteriorating environmental situation that has deepened poverty and reduced human wellbeing in all strata of Indian and Nigerian societies, leaders sought environmental governance as a tool aimed at addressing the human condition. But this was often without ideology and political

3 Our Common Future: The World Commission On Environment And Development, United Nations, Oxford 1987, p. 8. 
will with attendant consequences. The concomitant implication was a misconception and has called into question the true practical meaning of the term environmental governance in emerging democracies like India and Nigeria.

Today, there exist implementation gaps and weaknesses in the environmental governance processes of both countries. That induces noncompliance, and defective legal and institutional solutions. There is also a dialectical difficulty inherent in using 'judicial decision making' as a tool in the field of rule-based environmental governance architecture because the process of identification, of documentation of critical characteristics, and the evolution of universally acceptable solutions may be separate efforts. This notwithstanding, experience clearly shows that in the field of environmental governance, law and policy implementation are the most critical phases of a successful solution. ${ }^{4}$ To that extent it can be argued that a good environmental governance system is that which effectively combines the most suitable of several approaches that achieve the maximum voluntary or forced compliance or conformity. ${ }^{5}$

A survey of selected municipal legislations that deal with environmental governance in India and Nigeria shows that both countries have several laws and policies that regulate the topic. ${ }^{6}$ Most of these selected laws are in substance often written in "flowery language," but

${ }^{4}$ O.B. Bello, International Environmental and Legal Implications of Oil and Gas Exploitation in the Niger Delta of Nigeria, "Pro Quest" 2009, p.176.

${ }^{5}$ Ibidem.

${ }^{6}$ The Constitution of the Federal Republic of Nigeria; The Federal Environmental Protection Agency Act; The Environmental Impact Assessment (EIA) Act; Petroleum Act; Oil Pipelines Act; Minerals Act; Petroleum Profit Tax Act; Oil Terminal Dues Act; Associated Gas Re-injection Act; Nigerian Liquefied Natural Act; Oil in Navigable Waters Act; etc. See also The Constitution of India, Sections 268 to 290 of the Indian Penal Code (IPC) deal with environmental governance issues such as public nuisance like pollution of air and water, blasting, excessive smoke, filth, and other environmentally polluting activities. Also, several acts and policies like the Water (Prevention and Control of Pollution) Act 1974. The Environmental Protection Act 1986, Wildlife (Protection) Act 1972, Forest Conservation Act 1980, The Air (Prevention and Control of pollution) Act 1981, The Prevention of Cruelty Animals Act 1960, National Environmental Policy 2006, The National Green Tribunal Act 2010 have developed in India. Apart from these acts, there is other subsidiary legislation that deals with the issue of environmental governance at the federal, provincial, and at the municipal levels. 
the problem has been successful implementation. ${ }^{7}$ To most jurists this has precipitated environmental pollution; increased environment induced diseases; caused loss of biodiversity; diminished ecological capacity; poverty; social tension; debilitating corruption; poor environmental disaster preparedness; disaster risk management; lopsided; unsustainable development and environmental degradation in both countries. ${ }^{8}$

Ironically, the potential that the Judiciary could effectively develop environmental governance rules through distinct supervisory orders (including continuous mandamus) was, a few decades ago, hardly a focus of political cum governance discussion in either country. However, a careful analysis of the situation in both countries reveals that the general analytical hypothesis underlying environmental governance through the judicial decision making process, which situates human wellbeing and environmental sustainability. In other words, what this sustainable symbiotic relationship presents, is determined largely by the interactions between human choice, economic development, and what the law ought to be in both societies. Understanding these intricate interactions requires the central sustainable development methodology of the interdependence of humans and the environment, empirical analysis and interdisciplinary policy formation and implementation in plural ethnic societies such as India and Nigeria.

\section{ENFORCEMENT BY THE COURTS}

In both Nigeria and India, irrespective of the jurisprudential morality employed as a basis of environmental governance, the central theme seems predicated on the principle that as more and more citizens in these negatively impacted environments become aware of their legal rights they will in turn rely on citizen environmental law suits, which will in turn compel the governments, corporations, and other stakeholders to comply with environmental law and policy. These suits are usually based

7 IUCN Academy of Environmental Law Research Studies: Land Use Law for Sustainable Development: B.B. Orubebe, Environmental Impact Assessment Law and Land Use: A Comparative Analysis of Recent Trends in the Nigerian and U.S. Oil and Gas Industry, Cambridge - New York 2007, p. 301.

${ }^{8}$ Ibidem. 
on the public's right to information held by the governments, oil and gas corporations, and industry operators, as a fundamental human and/or environmental right. ${ }^{9}$ Be that as it may, the point needs to be explained that in countries, international and municipal environmental governance principles or right-based suits have been used by citizens and NGOs both as an accountability mechanism for government programmes and as part of their strategy to pressure private polluters or those otherwise harming the environment. ${ }^{10}$ These suits have over the years achieved varying degrees of success.

Another jurisprudential reality is the fact that in both countries the Courts are enjoined by the constitutions to adhere strictly to the principle of separation of powers. ${ }^{11}$ This raises a deep seated theoretical question to scholars and jurists alike, as to the role of the judiciary over the years. The theoretical analytical question posed here is whether a judge can make environmental law and policy in the course of interpreting law? John Austin of the legal positivist school of thought believes that the primary function or duty of the judge is to interpret the law as it is and not as it ought to be. ${ }^{12}$ On his part, Dennis Lloyd framed the jurisprudential thesis

${ }^{9}$ In 1992, the UN Conference on the Human Environment in Stockholm declared; "Man has the fundamental right to freedom, equality and adequate conditions of life in an environment of quality that permits a life of dignity and wellbeing." Arthur's Convention guaranteed the public's access to information, public participation in decision-making, and Access to Justice in Environmental Matters. The Rio Conference on Environment and Development declared: "Human beings are at the centre of concern for sustainable development. They are entitled to a healthy and productive life in harmony with nature." Universal Declaration of Human Rights, article 19, International Covenant on Civil and Political Rights, article 19, the European Convention, article 10 (1), American Convention, article 13, See also the African Charter on Human and Peoples Right, article 9. See also, D. Zaelke, D. Kaniaru, E. Kruzikova, Making Law Work: Environmental Compliance \& Sustainable development, Cameroon 2005 vol. 2, p. 13; D. Hunter, J. Salzman, D. Zaelke, International Environmental Law And Policy, New York 2002, pp. 1316-1317.

${ }^{10}$ Ibidem.

${ }^{11}$ Section 4 vested legislative powers in the National Assembly and Houses of Assembly, section 5 vested executive powers in the President and Governors - powers can be exercise by them personally or through the vicepresident, deputy Governors, ministers, commissioners, etc; while section 6 vested the judicial powers established by the constitution. See also Kehinde M. Mowoe, Constitutional Law in Nigeria, Nigeria 2008, p. 25.

12 J. Austin, R. Campbell, Lectures in Jurisprudence, London 1885. See also E. Tobi, Understanding Legal Method and Legal Theory, Nigeria 2002, p. 80. 
in the following words - The judge had no power whatever to make law but to simply declare it as it had always been. ${ }^{13}$ But Lord Denning posits that sending an inappropriate or inadequate law back to the legislature will waste precious time and not achieve the greater interest of justice. Hence in situations like this the judge can resort to his power of judicial review, which is an incident of interpretation, to fill the lacuna and thereby create a new law or rule by way or orders. There is no obstacle in the way of a judge, it is open for them to find a new tort or other approaches when there is none. ${ }^{14}$

This is the starting point for understanding these interactions, particularly identifying the jurisprudential 'parameters' and techniques employed by the judiciary in both India and Nigeria, in their attempts to resolve the otherwise conflict-laden interactions between the environment, development, and human wellbeing. In other words, the environmental governance typologies and the juridical summations underlying these interactions are (i) the role of the Courts in identifying and implementing environmental law as a basic or fundamental human right, (ii) the constitutional declaration or classification of environmental rights as a fundamental directive principle of State policy, (iii) the preparedness of courts to interpret existing laws to ensure the protection of the environment, (iv) the extent Courts incorporate existing environmental and sustainable development principles promoting interdisciplinary approaches, and (v) the Courts' ability to use environmental clearance as a necessary tool in the development project execution process and (vi) the Courts far-sighted environmental vision for both countries and the level of environmental awareness generated by the courts' decisions.

\section{THE INDIAN EXPERIENCE}

As we know, one of the biggest setbacks to environmental protection or governance is the inability of the judiciary, that is, the Courts, to identify and implement environmental law as a basic human right or, to say the least, the non-implementation of existing laws with a view

\footnotetext{
${ }^{13}$ D. Lloyd, The Ideal of Law, Harmondsworth 1979, p. 269.

${ }^{14}$ Ibidem.
} 
to upholding sustainable development. Here, the role of the judiciary is extremely significant. It is the judiciary's responsibility to ensure through interpretation of law and policy that the relevant and correct environmental governance principles or legal values are applied in its decision making process. According to S. RajendraBabu (Chief Justice of the Supreme Court of India, as he then was), it is now time to say what the law ought to be rather than what it is. If the executive branch does not discharge its duties, it is only natural for the judiciary to become more active and to protect the environmental rights of the common people. ${ }^{15}$

The widespread acceptance of judicial activism in India has helped the Courts to take a leading role in protecting the environment. Accordingly, the Supreme Court has stepped into the shoes of the administrator, using its authority to marshal resources, so as to require the strict implementation of environmental norms. Specific measures have included issuing directions to clean rivers, to remove garbage, to fix vehicle emission norms, to change crop patterns, to halt the construction of dams, and to restore forest cover. As a result of the activist role assumed by the Supreme Court, hundreds of factories have installed effluent treatment plants, many of our densely populated cities have become more livable in, forest cover has improved, and our air and water have become more clean and fresh. There is now an increased number of municipal officials involved in implementing the Court's orders. Our constant attention to the environment has also succeeded in mounting pressure on polluters. ${ }^{16}$

\subsection{IDENTIFYING AND IMPLEMENTING THE LAW}

In terms of Indian juridical history, a local magistrate and not the Supreme Court began the first historic environmental governance or protection measures of the Indian judiciary. ${ }^{17}$ In fact, section 133 of the Indian code of criminal procedure ironically - originally drafted during the colonial

15 S. Rajendra Babu, Environmental Law and Sustainable Development: Judicial Techniques Adopted By India's Supreme Court. (A Paper Presented at the Arab Chief Justices' Regional Conference and Symposium on Training of Judges and other Legal Stakeholders in Environmental Law and Sustainable Development, held at Cairo, Egypt 29-31 May 2004).

${ }^{16}$ Ibidem.

17 Ibidem. 
era 1898, allows the Courts "to order for removal of nuisance." 18 For about a century, although the statutes establishing the various Courts of record in India received this and other statutes as part of the received Common Laws of England and statutes of general application, jurist or legal scholar seriously bothered or impressed the judges to enforce this quintessential provision. But in the landmark Ratlam Municipality $v$. Vardichand case, ${ }^{19}$ however, all this changed.

The problem that the Court addressed in this case was monumental in many respects because it dealt with the daily life of millions of poor or 'better still' downtrodden people who out of poverty live in the slums. In these particular are as life is usually at the tipping edge and generally difficult due to the absence of sanitation, a proper drainage system, and, with no waste disposal system and the resulting environmental degradation, there are heaps of 'garbage accumulation' on the streets. But at the instance of a complaint by a citizen, a local magistrate, relying on the above provision and the Courts inherent summary trial powers, ordered the concerned municipality to remove the nuisance by constructing proper drains within a set time. The municipality objected, claiming they did not have the proper funds to comply with the directions of the magistrate. The matter thus got to the Indian Supreme Court on appeal, where the Court upheld the decision of the local magistrate, holding inter alia that "although these two Codes [Criminal Procedure Code and Indian Penal code] are of ancient and colonial vintage, the new social and environmental justice orientation imparted to them by the Constitution of India makes it a remedial weapon of versatile use." By so holding, the Supreme Court created a new environmental governance principle, law and policy that the environmental duties of public bodies were to be fulfilled without excuse.

18 Code of Criminal Procedure, 1973, s. 133. This provision confers summary powers on the magistrate to give directions for the abatement of public nuisance. If an order under s. 133 is disregarded, the penal powers under s. 188 of the Indian Penal Code will be triggered.

19 Ratlam v. Vardichand, [1980] 4 Supreme Court Cases 162 (Municipal Council) [hereinafter "Supreme Court Cases" is referred to as S.C.C]. 
Jurisprudentially, the Ratlam Municipality case in theory and practice gave a new life to the goal of addressing public nuisance. ${ }^{20}$ Thus, the Indian judiciary had established a means for environmental protection and prevention of pollution, and had done so independently of the implementation of the Environmental Protection $A c t^{21}$ or the Rio Declaration. It is therefore not how many laws a country has, but how effectively these existing laws are implemented that matters.

\subsection{INTERPRETING EXISTING LAWS SO AS TO ENSURE THE PROTECTION OF THE ENVIRONMENT}

Article 21 of the Indian Constitution guarantees the fundamental right to life for all persons. ${ }^{22}$ The right to life includes all aspects of life that makes a human's life meaningful, complete, and 'worth living'. ${ }^{23}$ This constitutional proviso is generally believed to cover environmental governance principles because the right to life presupposes a good environment, sustainable choices, etc. that enhance the right to make a living. ${ }^{24}$ The basic jurisprudential principle emphasized here is that a constitution is linked to its organic mode of origination. ${ }^{25}$ So the basic objective of the Indian judiciary's role in environmental governance or protection is to fashion the Court's interpretation technique towards set aims and objectives. In other words, as a result of the liberal interpretation given to the words 'life' and 'liberty', Article 21 has now come to be invoked almost as a residuary or instrumental right - to an extent the framers of the Indian Constitution and the judges who gave it the initial gloss never dreamed of. ${ }^{26}$

${ }^{20}$ See K.R.J. Rao, Use of Criminal Machinery for Environmental Protection, The Practical Lawyer, available at: http://www.supremecourtcases.com/index2.php?option=com_ content\&itemid=5\&do_pdf=1\&id=1007.

${ }^{21}$ India enacted the Environmental Protection Act in 1986.

${ }^{22}$ Article 211 of the Constitution of India reads as follows: "No person shall be deprived of his life or personalliberty except according to the procedure established by law."

${ }^{23}$ Maneka Gandhi V. Union of India, [1978] 1 S.C.C. 248

${ }^{24}$ Olga Tellis v. Bombay Municipal Corporation, [1985] 3 S.C.C. 545.

25 O.D. Juma, Constitution Making and Democratization Trends in Africa, "East African Law Journal" 2004, vol. 1, p. 21.

${ }^{26}$ D.D. Basu, Shorter Constitution of India, Allahabad 2001, p. 265. 
Axiomatically, this is the heroic background and as a result thereof, a plethora of remarkable and cum innovative jurisprudential developments particularly, the far-sighted interpretation of the right to life, many otherwise non-justiciable directive principles entrenched in Part IV of the Indian Constitution have now been resurrected as enforceable fundamental rights by the 'magic wand' of judicial activism. ${ }^{27}$ It is trite that the responsibility to improve the environment is only a directive principle under the Indian Constitution, ${ }^{28}$ but by giving liberal interpretation to the fundamental right to life, the Indian Supreme Court have through its decision making, made the right to a clean environment an integral part of Article 21..$^{29}$

Another critical steep turn in the theoretical analysis of the techniques used by the Courts, and in particular the Indian Supreme Court, is the development and conceptualization of the inherent powers of the Court to make ancillary or consequential orders. Through this the Supreme Court of India has created new objective-specific object specific executive structures and in the process resolved otherwise difficult environmental disputes on the one hand and, on the other, synchronized or coordinated the sometimes chaotic judicial orders in a constitutional federation.

For example, the hallmark case T. N. Godavarman Thirumulpad $\mathrm{V}$. Union of India ${ }^{30}$. In this case which was originally filed as a writ petition in the Supreme Court of India to protect the Nilgiris forest which was on the verge of extinction due to continuous deforestation by illegal timber operations, the Supreme Court reinterpreted the Forest (Conservation) Act 1980 and expanded the scope of the term "forest", and suspended tree felling across the country. Ironically, the case was heard by the Court over several years, essentially, for numerous procedural

${ }^{27}$ Ibidem. See generally S.R. Babu, Environmental Law and Sustainable Development: Judicial Techniques Adopted By India's Supreme Court. (A Paper Presented at the Arab Chief Justices' Regional Conference and Symposium on Training of Judges and other Legal Stakeholders in Environmental Law and Sustainable Development, held at Cairo, Egypt, 29-31 May 2004).

${ }^{28}$ Article 48A of the Constitution of India states as follows: "The State shall endeavour to protect and improve the environment and to safeguard the forests and wild life of the country."

\footnotetext{
29 A.P. Pollution Control Board v. A. P. Nayudu, [2001] 2 S.C.C 63.

${ }^{30}$ T. N. GodavarmanThirumulpad V. Union of India, (1996) 9 S.C.R. 982.
} 
reasons and delays. As a smart check or innovation to account for the years of delay the Court in exercising its inherent and ancillary powers evolved what later became known as the "continuous mandamus", in which the Court, rather than passing final judgment, continues to pass orders and directions with a view to monitoring the functioning of the executive, and in particular, compliance with Courts' environmental governance or protection orders.

Perhaps the most remarkable result arising from this case was the creation of new structures such as the National Level Committee on Forestry popularly known as the Central Empowered Committee (CEC) which has been created under the Environment Protection Act. ${ }^{31}$ The Indian Supreme Court order in this case had far reaching consequences on forest governance in the Northeastern region of India because the Court in an order banned the movement of cut trees from the states of Northeast India to other states of the country. However, the Supreme Court modified its order dated 23.04.2001 and stated that the movement of sawn and unsawn timber from the Northeastern States shall be permitted on the intent of the District Forest Officer or any other authorized Forest Officer on an application made by the registered timber transporter. In the case that any illegal timber is found to be transported, the forest official concerned under whose supervision and control the seal has been affixed on the railway wagon, will be prosecuted ${ }^{32}$. In the event that the seals are tampered with, the railways can also be held culpable. ${ }^{33}$ The responsibility of the above two is in addition to the primary responsibility of the registered timber transporter on whose application the incident occurred. The Supreme Court further stipulated that such movement of

${ }^{31}$ See also 14 Vellore Citizen's Welfare Forum Vs Union of India and Ors decided on 28th August 1996, available at: http://www.indiankanoon.org/doc/1934103/ [last accessed 15 April 2015].

32 Infra note 34.

${ }^{33}$ This principle is 'worker financial incentives' based corporate governance modules. It requires a corporation work programme to be streamlined with environmental compliance codes/guidelines and when targeted goals are achieved the employee receives 'linked bonuses or salaries or other form of monetization' - (including wage increase or other financial reward). But if there is a breach the individual worker takes strict responsibility and could be prosecuted. Under this approach compliance with environmental law and policy is observed and seen as part of employees training and routine job schedule. 
sawn and unsawn timber shall be permitted only if the High Powered Committee (HPC) cleared wood based units situated inside approved industrial estates except in respect of Mizoram where no industrial estates exist. This order of specificity as issued on the direction of the Supreme Court clarifies the subsisting order to the effect that hand sawn timber, save in cases where specific approval is accorded by the High Powered Committee (HPC)/Ministry of Environment and Forest (MoEF), shall not be allowed to be transported outside the North East except in the case of Mizoram.

In several respects, the Godavarman's case is a classic example of how the Supreme Court of India's' intervention brought about a great deal of positive environmental governance practices in a nascent democracy. ${ }^{34}$ Cumulatively, the ancillary orders made by the Court in the T.N. Godavarman's Case had far reaching environmental governance implications in the regions and the entire federation of India in three lucid ways. Firstly, for the first time in the history of India and in particular - forest management, the movement of timber from the Northeast India to other locations in the country was banned. Secondly, the Court's far-sighted policy strategy on dealing with the critical environmental governance issues was enunciated in a comprehensive manner, which actually started with the directions on the Northeastern regional government. This was followed by the composition of the now famous High Powered Forest Committees, and subsequently led to the centralized environmental statistics or data collation on afforestation and deforestation, which for all purposes and intents marked the beginning of coordinated research information on forest and wood based industries, centralized and integrated reporting, and compliance monitoring with sectorial and local area specific targets being made integral parts of a carefully thought out strategy of the Court. Thirdly, the Court ordered that there shall be no fresh felling of trees in the affected forests belonging

34 T.N Godavarman, Case order dated 13-01-1998, Washington 2007, available at: http:/ / elr.info/sites/default/files/articles/37.10032.pdf. Note that the Northeastern states (Arunachal Pradesh, Assam, Manipur, Meghalaya, Mizoram, Nagaland, and Tripura) like their Niger Delta counter parts of Nigeria are indigenous ethnic minorities whose ancestral home lands are very rich in natural resources particularly the forest resources with deposits of natural minerals. 
to the Government, district and regional councils until the disposal of their existing stocks of legal and illegal timber.

In all, the most critical constitutional and environmental governance law, policy, and principle in this case is the order dated 13 January 1998 which affirmed retrospectively, that existing inventories and stocks of timber originating from plantations in private and community holdings in the States of Meghalaya, Mizoram, Tripura, Manipur, and Nagaland may be disposed of by their owners under the relevant State laws and rules. ${ }^{35}$ Dialectically, this case is historic and opened a new vista in environmental governance in India and the developing countries, but critics believe that, although decisive action may have been necessary, the Supreme Court's orders made demands far beyond its control. The Supreme Court assumed too much power too quickly to effectively manage it. Its orders may have been logically sound, though incomplete, from a policy perspective, but from a practical perspective, they demanded too much from India's weak state and local governments. The Supreme Court did not exercise sufficient caution in extending its role to directly oversee forestry issues. ${ }^{36}$

\section{INCORPORATING WELL-KNOWN PRINCIPLES INTO THE LOCAL BODY OF LAW}

Over the years, owing to consistent effort by judges in the Supreme Court, it is now typical in Indian judicial circles for Courts to uphold the application of innovative environmental governance principles regardless of the odds. This was to say the least what happened in the historic case of Indian Council for Environmental Legal Action v. Union of India. ${ }^{37}$ In this case the Supreme Court applied the "polluter pays" principle to the actions of several large chemical industries. The companies had not obtained requisite clearances and started polluting a village

${ }^{35}$ Available at: laisharamcha-ji-nine-meetei-vs-state-of-manipur-and-ors.pdf [last accessed on 21 April 2015].

${ }^{36}$ A. Rosencranz, E. Boenig, B. Dutta, The Godavarman case: The Indian Supreme Court's Breach of Constitutional Boundaries in Managing India's Forests, available at: http:/ / elr.info/ sites/default/files/articles/37.10032.pdf [last accessed on 8 June 2015].

37 Indian Council for Enviro Legal Action v. Union of India, [1996] 3 S.C.C 212. 
through a series of hazardous activities. As toxic substances polluted the ground water and noxious fumes filled the air, life in the village became difficult and some of the industries were closed following public agitation, but the consequences of their actions remained. Acting upon a Public Interest Litigation (PIL), the Court applied the "polluter pays" and strict liability principles, and compelled the polluters to pay for their actions. By applying the concept of absolute liability, the Indian judiciary raised the jurisprudential 'bar' beyond other $19^{\text {th }}$ century strict liability principle requirement regimes. ${ }^{38}$ This refinement followed well established environmental principles earlier laid down by the Court in the M. C. Mehtra v. Union of India, case, ${ }^{39}$ where the Court held inter alia that industries engaged in hazardous or inherently dangerous activities are absolutely liable when death or danger occurs in the course of their activities.

In such cases, no exculpatory defence is available to the defaulters. Such industries are strictly and absolutely liable for the damages of all those who are affected by the accident, as part of the social cost of their activity. If an enterprise is permitted to carry on a hazardous or inherently dangerous activity for its own profit, the law must presume that such permission is conditional on the enterprise absorbing the cost of any accident without excuse.

In every respect the passion of the Indian Supreme Court on environmental governance and sustainable development is rated very highly in comparative terms. Another earned accolade is that in environmental governance matters, the Indian judiciary is no respecter of persons. In fact, as reported, perhaps correctly too, the Court followed up on a news item $^{40}$ in a national daily report that a private company linked to the family of Kamal Nath, a former Minister of Environment and Forest, had built a club on the River Beas by encroaching on land, including substantial forest land, which was later regularized and leased out to the company when Kamal Nath was the minister. The article also reported that the company had used bulldozers to change the course of the river in order to save the motel from future floods. The Supreme Court

${ }_{38}$ The strict liability principle was developed in Rylands v. Fletcher, [1868] LR 3 HL 330.

39 M. C. Mehtra v. Union of India, [1987] 1 S.C.C 395.

40 Anonymous, Kamal Nath dares the mighty Beas to keep his dreams afloat, "Indian Express", 25 February 1996. 
took judicial notice of the news item and quashed the earlier clearance given by the government in M. C. Mehta v. Kamal Nath. ${ }^{41}$ Here, the Court held that the natural resources, ecosystems, and the environment are vested in the state as trustee. ${ }^{42}$ As a gift of nature, the resources should be made freely available to everyone irrespective of social status. The state cannot allow public land to be converted into private ownership for personal profit; it is necessary that the state act only in good faith for the public good and in the public interest. In the case discussed above, ${ }^{43}$ the Court further found that the impugned lease transactions were in clear breach of the public trust held by the state. ${ }^{44}$

In the Vellore Citizens Welfare Forum V. Union of India ${ }^{45}$ case the precautionary principle of environmental governance was established as an integral part of Indian judiciary's methodology in addressing the environmental malaise plaguing the Indian society. No doubt, this spirited effort by the Indian judiciary has produced important results such as the doctrine of intergenerational equity and the concept of sustainable development. Thus what the judiciary in India appears to be doing is to identify best practice elsewhere and to kick-start their implementation when the occasion presents itself inform of disputes.

\section{IDENTIFYING THE AREAS THAT REOUUIRE THE COURT'S INTERVENTION AND ISSUING. NECESSARY DIRECTIONS}

In Subhash Kumar v. State of Bihar ${ }^{46}$ the Court held inter alia that the right to pollution-free air and water were guaranteed fundamental rights. Our

${ }^{41}$ M. C. Mehta v. Kamal Nath, [1997] 1 S.C.C 388.

${ }^{42}$ The Roman Empire developed the public trust doctrine. Though the public trust doctrine under English common law extended only to certain traditional uses, such as navigation, commerce, and fishing, American courts expanded the concept. See generally J. L. Sax, Public Trust Doctrine in Natural Resource Law: Effective Judicial Intervention, "Michigan Law Review" 1969, vol. 68, p. 473, part 1.

${ }^{43}$ M. C. Mehta v. Kamal Nath, [1997] 1 S.C.C 388.

${ }^{44}$ Ibidem.

45 Vellore Citizens Welfare Forum v. Union of India, [1996] 5 S.CC.647 (Vellore Citizens).

${ }^{46}$ Subhash Kumar v. State of Bihar, [1991] 1S.C.C 598. See also Vellore Citizens Welfare Forum v. Union of India, [1996] 5 S.CC.647 [Vellore Citizens]. 
Courts have enforced this right time and again. ${ }^{47}$ In one of the M. C. Mehta cases ${ }^{48}$ the Court even compelled the central government to place the Indian national Policy on Environment before the Supreme Court for implementation monitoring.

This was to a large extent against the broad background of the implications of law and policy gaps, and the Indian Supreme Court through this and related directives developed the jurisprudential theory that fundamental rights are inalienable and a proven basis for the existence of government. To ensure the proper protection of fundamental rights, the Court established the rule based environmental governance technique of Public Interest Litigation (PIL), the advanced Indian hybrid version of United States of America class action suits in which the substantive and procedural requirement of locus standi is relaxed. This has increased access to the Courts, under the conceptualization of Public Interest Litigation. The theoretical proposition here is that regardless of Court rules, orders, and forms, a private citizen can write a letter, signed or anonymous, and send it directly to the Supreme Court or to any high Court for the purpose of protecting the fundamental right to a safe environment, and he may do so on his own on behalf of a poor rural community. ${ }^{49}$ In Bahdhua MuktiMorcha v. Union of India, ${ }^{50}$ the Court relaxed its forms as required by the rules of Court and did not even insist on an affidavit as a condition for entertaining a letter. If we adhered to the technical requirements of complains in such cases, the entire purpose of the laws would be frustrated because the majority of poor and disadvantaged persons would not have easy access to the Courts. ${ }^{51}$

Also, in Rural Litigation and Entitlement Kendra v. State of U. P. referred to as the Dehra Dun quarry case in some media reports, ${ }^{52}$ the Supreme Court acted upon a letter sent by an organization and forbade

${ }^{47}$ M.C. Mehta v. Union of India, [1987] 4 S.C.C 463; Rural Litigation and Entitlement Kendra v. State of U. P. No.1 [1986] Supp. S.C.C 517; Rural Litigation and Entitlement Kendra v. State of U. P. No. 2 [1989] Supp. 1 S.C.C.504; and Rural Litigation and Entitlement Kendra v. State of U. P. No. 3, [1991] 3 S.C.C. 347.

${ }^{48}$ M. C. Mehta v. Union of India, [1998] 9 S.C.C. 589.

49 Supra note 16.

${ }^{50}$ Bahdhua MuktiMorcha v. Union of India, [1984] 3 S.C.C 161.

51 Bahdhua MuktiMorcha v. Union of India, [1984] 3 S.C.C 161.

${ }^{52}$ Rural Litigation and Entitlement Kendra v. State of U. P. [1986] Supp. S.C.C 517. 
an unsustainable act of limestone quarrying in the interest of preventing ecological imbalance. By using creative interpretation, the absence of law was never a big hurdle in the way of the Indian Courts' making interlocutory of ancillary orders, pass or directions on issues relating to the protection of the environment.

Transformational leadership of the judiciary in India has encouraged Judges and Courts sitting over environmental governance related suits to identified issues and areas requiring judicial intervention. A lot more was due to the leadership preferences demonstrated by Chief Judge of India at any given time and the personal appreciation by judges of the need to address the human condition as integral to environmental governance and sustainable development goals. Thus the changed jurisprudential perception has induced the development of more efficient environmental governance rules, which are based on scientific knowledge and technological innovations, which further stimulate object specific judicial techniques that required and ordered polluters of environmental or natural resources such as the Ganga River ${ }^{53}$ to establish effluent treatment plants before they were allowed to continue their business operations. ${ }^{54}$ The Courts rejected the industries' arguments of poor financial condition and compelled all of them to set up treatment plants within flexible, but specified, periods. ${ }^{55}$ This act eventually had an exponential cost benefit effect for the initially reluctant industries, due to increased competiveness regionally and globally. It can thus be demonstrated empirically that the Indian judiciary's aggregation of federal, provincial, and municipal responsibilities or owed constitutional and statutory duties has helped identify erring agencies, governments, and, more particularly, the local municipal councils in such cases, and has given time-specific directions to protect the environment including rivers. ${ }^{56}$

${ }^{53}$ The Ganga River is to India as the Niger and the Atlantic Ocean is to Nigeria. In fact, both rivers along with several other rivers played a pivotal role in shaping indigenous Indian and Nigerian culture and civilizations. It is trite that millions of ordinary people depend of these rivers for their daily needs.

${ }^{54}$ M. C. Mehtra v. Union of India, [1987] 4 S.C.C 463, and [1992] Supp. i 2 S.C.C. 633 and 637.

${ }_{55}$ M. C. Mehtra v. Union of India, [1997] 2 S.C.C 411.

${ }^{56}$ M. C. Mehtra v. Union of India, [1998] 1 S.C.C. 471 
The crises in Indian environmental governance were manifest in marked imbalances and inaction on the part of the executive. So the judiciary in order to protect the environment has aggressively intervened with techniques, sometimes with punitive fines, that guaranteed implementation or compliance. For example, in M. C. Mehtra v. Union of India ${ }^{57}$ case, the Court made orders that prevented vehicular pollution in order to ensure clean air. In M. C. Mehtra v. Union of India, [2002] 4 S.C.C $C^{58}$ also referred to as the GNG case, the Court directed the Delhi administration to forbid diesel buses or vehicles from Delhi roads and to compel the provision of the cleaner CNG fuel for all vehicles from Delhi roads and CNG fuel for all vehicles. This was through the enforcement of punitive fines, levies, and rebate fees imposed on violators who eventually had no choice but to comply. For the short and long time effects the Court's consistent and structured fixing or better still, imposition of these penalty regimes has brought about improved vehicle emission standards. As a result, the Indian capital city, Delhi, has become one of the cleanest cities in the World.

India like Nigeria is a constitutionally secular state, but the issue of religion, particularly prayers, is sensitive and political leaders prefer to avoid confronting or taken on such issues. This notwithstanding, in Church of God (Full Gospel) in India v. K. K. K. Majestic Colony Welfare Assn, the Court without fear of political backlash enunciated the environmental governance rule that prohibited noise pollution created by religious activities. In this case a particular sect of Christians regularly prayed using loudspeakers and drums, and the noise they were making had become a nuisance for the people in the locality. The polluters claimed that their right to religion includes the right to loud prayers. But the Court held that that such activity is noise pollution and an inconvenience to the people in the colony. The Court forbade loud prayers forthwith. ${ }^{59}$ On the whole the Court has used the instrumentality of Court orders to improve the environment in several other ways such as the preservation

57 Ibidem.

${ }^{58}$ M. C. Mehtra v. Union of India, [2002] 4 S.C.C. 356.

${ }^{59}$ Church of God (Full Gospel) in India v. K. K. K. Majestic Colony Welfare Assn, [2007] 7 S.C.C 282. 
of the forest, ${ }^{60}$ the protection of the marine environment, the protection of animals, ${ }^{61}$ improved conservation of marine resources such as the directive on safe shrimp farming, ${ }^{62}$ the sustainable development of coastal zones protection through regulation ${ }^{63}$, and has prohibited the general location or relocation of polluting industries from densely populated areas in order to protect the environment. ${ }^{64}$

\section{MAKING ENVIRONMENTAL CLEARANCE ASTRICT REOUIREMENT FOR ALL PROJECTS}

Typically, experience has showed that environmental governance is knowledge driven and knowledge of the environment is the synthesis form and contents of conceptual frame provided by interdisciplinary knowledge. Hence, one natural outcome of the leading role of India's judiciary was the deluge of large number of environmental cases, a fact that necessitated the establishment of a separate tribunal called Green Tribunal for hearing such cases. Analytically, this has helped the Courts develop precise rule-based procedures that allow environmental experts and scientists to dispassionately deal with issues of concern. The establishment of National GreenTribunals or Benches ${ }^{65}$ in all the High Court Divisions has played a significant role in the evolution of universally applicable shared techniques such as the requirement of environmental clearance and continuing compliance with such conditions for clearance. For example in Essar Oil Ltd. V. HalarSamiti, the Court directed the closure ofthe company's operations because it did not comply with their environmental pre-conditions. ${ }^{66}$ Also in Alimtra H. Patel

${ }^{60}$ T. N. Godavarman Thirumukpad v. Union of India, [2001] 10 S.C.C 645.

${ }^{61}$ Navin m. Raheja v. Union of India, [2001] 9 S.C.C 762.

62 S. Jagannath $v$. Union of India [1997] 2 S.C.C 87.

${ }^{63}$ Indian Council for Enviro Legal Action v. Union of India, [1995] 3 S.C.C 77; and Bittu Seighal v. Union of India[2001] 9 S.C.C 181.

${ }^{64}$ M. C. Mehtra v. Union of India, [2001] 4 S.C.C. 577.

65 Vellore Citizen's Welfare Forum v. Union of India and Ors decided on 28th August 1996, available at http:/ / www.indiankanoon.org/doc/1934103/ [last accessed on 15 April 2015].

${ }^{66}$ Essar Oil Ltd. v. Halar Samiti, [2004] 2 S.C.C 392. See also Tarun Bharat Singh v. Union of India, [1993] Supp.3 S.C.C 115. 
v. Union of Indiathe Court developed the open ended or continuous mandamus technique to keep the matter open while monitoring the company's compliance ${ }^{67}$ In other instances the spirited intervention of the Indian Supreme Court has delayed even multi-million dollar projects such as the construction of large dams Narmada Bachao Andolan v. Union of India ${ }^{68}$. In these cases, the Court required strict compliance with environmental clearance conditions. Here the Court further enunciated the practice rule of issuing continuing mandamus that compelled the company to report to the Court on step by step adaptive environmental management compliance reporting until the final expected outcome or result was achieved. In practice, the judicial technique of "hands on" close scrutiny and supervision with the award of punitive fines and appropriate damages has compelled environmental compliance across the country. ${ }^{69}$

\section{SPREADING AWARENESS}

No doubt, in the last few decades India has developed a considerable number of environmental policies and laws through the engaged involvement of the judiciary. These developments have resulted in the enunciation of several environmental governance principles that deal with issues like environmental degradation, afforestation, cruelty to animals, public nuisance, pollution of air and water, blasting, excessive smoke, filth, inadequate drainage, sanitation, flooding, and oil and gas pollution. All these remarkable efforts were against the background, of a vastly illiterate population with an inadequate awareness of the essence of these bands of environmental endeavours. To address these and other challenges the Court in M. C. Mehtra v. Union of India, ${ }^{70}$ was forced to issue orders or directives to the government and related bodies to include lessons on the environment and its protections in school and university syllabi. Courts can also take proactive steps to create awareness among

\footnotetext{
${ }^{67}$ Alimtra h. Patel v. Union of India, [2000] 2 S.C.C. 679.

${ }^{68}$ Narmada BachaoAndolan v. Union of India, [2000] 10 S.C.C. 664; and N.D. Jayal v. Union of India, [2003] Supp. 2.

${ }^{69}$ M.C. Mehta v. Kamal Nath, [2000] 6 S.C.C 213.

${ }^{70}$ M. C. Mehtra v. Union of India, [1991] 1 S.C.C. 358, and [2000] 9 S.C.C. 411.
} 
citizens. We must also ensure the awareness of state bureaucrats and the lower levels of the judiciary, so that we are all sensitized to the issues confronting the Indian nation. ${ }^{71}$

\section{LOOKING FORWARD}

Contrary to the traditional view, the Courts in India have assumed the extra responsibility to give the country a sense of direction in the future. To this end, several schools of thought have emerged on the best method to resolve the basic issue of conflict between development and the environment. In the hallmark case Vellure Citizens Welfare Forum v. Union of India, ${ }^{72}$ the Indian Supreme Court insisted that:

the balance between environmental protection and developmental activities could only be maintained by strictly following the principle of 'sustainable development." This is a development strategy that caters to the needs of the present without negotiating the ability of upcoming generations to satisfy their needs. The strict observance of sustainable development while protecting the environment is a path that works for all peoples and for all generations. It is guaranteed to the present and a bequest to the future. All environmentally related development activities should provide a benefit for the people while maintaining environmental balance. This could be ensured only by the strict adherence to sustainable development, without which the lives of coming generations will be in jeopardy."73

In N.D. Jayal v. Union of India ${ }^{74}$ the Court reiterated its future environmental policy. In this case, the construction of a dam was challenged on the grounds of safety, non-compliance, and environmental degradation. The Court in the course of dealing with the basic issue of development versus

${ }^{71}$ S. R. Babu, Environmental Law and Sustainable Development: Judicial Techniques Adopted By India's Supreme Court. (A Paper Presented at the Arab Chief Justices' Regional Conference and Symposium on Training of Judges and other Legal Stakeholders in Environmental Law and Sustainable Development, held at Cairo, Egypt, 29-31May, 2004).

72 Vellure Citizens Welfare Forum v. Union of India, 1996 (5) SCC 647.

${ }^{73}$ Ibidem.

${ }^{74}$ N.D. Jayal v. Union of India, [2003] Supp. 2.

M.C. Mehta v. Kamal Nath, [2000] 6 S.C.C 213. 
environment, decided the case inter alia by adhering to the principle of sustainable development.

The United Nations conceives a global future in which the right to development will be basic, in fact, indispensable, in any human endeavour. Hence the need for it to be fairly distributed among the people of any country so that each and every person may realize his or her right to development. ${ }^{75}$ According to the United Nations Declaration on the Right to Development, Article 1(1),

The right to development is an inalienable human right by virtue of which every human person and all peoples are entitled to participate in, contribute to, and enjoy economic, social cultural and political development, in which all human rights and fundamental freedoms can be fully realized. ${ }^{76}$

Article 8 further calls upon all UN Member States to take all measures necessary for the equal enjoyment of basic resources and equal participation in matters of development ${ }^{77}$. In Samata $v$. State of Andhra Pradesh ${ }^{78}$ and Madhu Kishore v. State of Bihar. ${ }^{79}$ The Court reaffirmed without equivocation the right to a clean environment, a guaranteed fundamental right under the scope and meaning of the Indian Constitution. Also, under distinct but similar contexts the Court has also declared that the right to development is also a component of Article 21. The right to development cannot be treated as a mere right to economic gain and cannot be limited by the misnomer of 'construction activities'. The right to development encompasses much more than economic well-being, including within its scope the guarantee of fundamental human rights. In India, a far-sighted Supreme Court has evolved the conceptualization that 'the issue of development cannot be separated from the conceptual framework of human rights." The right to development is dependent

${ }^{75}$ K.A. Achempong, Upholding the Concept of the Universality of Human Rights: Some Current Jurisprudential Concerns Regarding the Zimbabwe Land Issue, "The University of Nairobi Law Journal" 2004, vol. 2, issue 1, pp. 29-40.

${ }^{76}$ United Nations Declaration on the Right to Development, Article 1(1), adopted by the General Assembly of the United Nations through its Resolution 41/128 of $4^{\text {th }}$ December 1986.

77 Ibidem.

78 Samata v. State of Andhra Pradesh, [1997] 8 S.C.C. 191.

${ }^{79}$ Madhu Kishore v. State of Bihar,[1994] 5 S.C.C. 125. 
on a whole spectrum of human rights, but is also an integral part of achieving these rights. In practice, these principles are legitimate aims and aspirations in civil, cultural, economic, political, and social processes for the improvement, of people's well-being and the realization of their full potential. Construction of a dam or a mega project can definitely be an attempt to achieve the goal of wholesome development and should be treated accordingly. ${ }^{80}$ Therefore, adherence to the principle of sustainable developments is a sine qua non for the maintenance of the symbiotic relationship between the rights to a clean environment and to development. This principle was enunciated in the case A. P. Pollution Control Board II v. M. V. Nayudu, ${ }^{81}$ where the Court held that "the concept of a healthy environment is as a part of the fundamental right to life." In effect, the Court has crystalized the environmental governance doctrines such as intergenerational equity, ${ }^{82}$ the public trust doctrine ${ }^{83}$, and the precautionary principle, ${ }^{84}$ as inseparable ingredients of the emerging environmental governance jurisprudence, aimed at achieving sustainable development.

The Indian Supreme Court has been emphatic in its interpretation of the Environmental Protection Act 1986 (as amended) action forcing. Thus the object and purpose of the statute is among others, "to provide for the protection and improvement of the environment," that can only be achieved by ensuring strict compliance with its provisions.

\subsection{The Nigerian JUdicial EXPERIENCE}

Nigeria like India is a constitutional democracy. Section 20 declared the environmental governance objective that the Nigerian State shall protect and improve the environment and safeguard the water, air and land, forest, and wild life, of Nigeria. ${ }^{85}$ To most constitutional law scholars:

80 Supra note 16.

81 A. P. Pollution Control Board II v. M. V. Nayudu, [2001] 2 S.C.C. 62.

82 State of Himachal Pradesh v. Ganesh Wood Products, [1995] 6 S.C.C. 363.

${ }^{83}$ M. M. Mehta v. Kamal Nath, [1997] 1 S.C.C. 388.

${ }^{84}$ Vellure Citizens Welfare Forum v. Union of India, 1996 (5) SCC 647. See also Supra note 16 .

${ }^{85}$ Constitution of Nigeria section 20 [1999]. 
by fundamental objectives we refer to the identification of the ultimate objectives of the Nigerian Nation whilst Directive Principles of State Policy indicate the paths which lead to those objectives. Fundamental Objectives are ideals towards which the Nigerian Nation is expected to strive whilst Directive Principles lay down the policies which are expected to be pursued in the efforts by the Nigerian Nation to realize the national ideals.... ${ }^{86}$

The above theoretical standpoint was entrenched in the Nigerian grand norm. Section 6 of the Nigerian constitution provided in part that:

The judicial powers of the federation shall be vested in the Courts.

The judicial powers vested in accordance with the foregoing provisions of this section-

(6) (a) Shall extend, notwithstanding anything to the contrary in this constitution, to all inherent powers and sanctions of a Court;

(b) Shall extend to all matters between persons, or between government or authority, and to any person in Nigeria, and to all actions and proceedings relating thereto, for the determination of any question as to the civil rights and obligations of that person;

(c) Shall not, except as otherwise provided by this Constitution, extend to any issue or question as to whether any act or omission by any authority or person or as to whether any law or any judicial decision is in conformity with the Fundamental objectives and Directive Principles of State Policy set in Chapter 11 of this Constitution;

The above rather curious proviso according to some scholars means in effect that:

...the non-attainment of environmental objectives and failure of the state to protect and safeguard the environment cannot be questioned in any Court. But it should be noted that the mere provision that these principles are not justiciable does not per se divest them of legal value. To this end the fact that to protect and safeguard the environment is not judicially enforceable does not mean that where such failure impinges on the fundamental rights which

${ }^{86}$ G.N Okeke, Fundamental Objectives and Directive Principles of State Policy under the Nigerian Constitution in: Report of the Constitution Drafting Committee 1979-1988, “Nnamdi Azikiwe University Journal of International Law and Jurisprudence" 2011, vol. 2, p. 74 . 
are justiciable that the Court shall ignore this violation... This is because the Directive Principles ... have to conform to and run as subsidiary to the chapter on Fundamental Rights. ${ }^{87}$

The view that environmental rights are non-justiciable or enforceable with a compound reading of sections 20 and 6(6)(c) is, to say the least, begging the question and not supported by the plain and unambiguous provisions above referred for two simple reasons. Firstly, the said section 6 vests unlimited judicial powers in the Courts. Section 6(6)(a) sets the jurisprudential parameters of the judicial powers the Courts are enjoined to exercise that is, notwithstanding anything to the contrary in this constitution and shall extend to the inherent powers and sanctions of the Court. At best section 20 and 6(6)(c) are contrary provisions in no way/by no means incapable... of precluding any Court disposed to give effect to environmental governance or protection as a right. Secondly, the jurisprudential justification of the instrumental environmental right is that it is generic and the basis upon which other human rights are enjoyed or actualized. In practice, it need not be gainsaid that environmental right is an amalgam of all the instrumental human rights that pertain to all human beings at all times and forms the fulcrum of the basis or justification for the enjoyment of all other rights howsoever described. This in effect means that environmental governance rights constitute, collectively a condition sine qua non for our normative nature as human beings. This right has an impact on every aspect and philosophy of life..$^{88}$ They are organic inalienable rights, and although codified in international, ${ }^{89}$ regional ${ }^{90}$ and

87 Ibidem, p. 82. See also E. Onyeabor, Addressing Pitfalls in Environmental Protection Laws in the Oil Sector for Effective Human Rights Protection, "Environmental \& Planning Law Review" 2005, vol. 2, issue 4, p. 1.

${ }^{88}$ K.A. Achempong, Upholding the Concept of the Universality of Human Rights: Some Current Jurisprudential Concerns Regarding the Zimbabwe Land Issue, "The University of Nairobi Law Journal" 2004, vol. 2, issue 1, p. 29-32.

${ }^{89}$ Universal Declaration of Human Rights, December 10, 1948, U.N. G.A. Res. 217 (111 1948).

90 African Charter on Human and Peoples Right(Banjul Charter), June 27, 1981, 21 I.L.M 59 (1981). See also American Convention on Human Rights, November 22, 1969, I.L.M 673(1970). Charter of Fundamental Rights of the European Union, O.J.C 364/1 (December 18, 2000). 
national ${ }^{91}$ human right instruments, the source of rights as the inherent human environment and the right to life of human beings therein predates instruments. At best constitutions provided codified legal frameworks or better still, instruments for their actualization. Notably, such codified protection is important for the enjoyment of these rights. In the words of Shridath Ramphal, former Secretary-General of the Commonwealth:

....rights are as old as human society itself, for they derive from every person's need to realize his essential humanity. They are not ephemeral, not alterable with time and place and circumstance. They are not the product of philosophical whim or political fashion. They have their origin in the fact of the human condition; and because they have, they are fundamental and inalienable. More specially, they are not conferred by constitutions, conventions or governments. These are the instruments, the testaments, of their recognition. They are important, sometimes essential, elements of the machinery for their protection and enforcement; but do not give rise to them. They were born of man but with man.... ${ }^{92}$

The debate on whether sections 20 and 6(6)(c) of the Nigerian constitution derogate from the universally acclaimed environmental governance right is poignant and a matter of recurrent debate. But the view and context 1 adopted in this paper is the efficacy of the judiciary in promoting environmental governance and sustainable development, regardless of constitutional obstacles shrouded in prescriptive technicalities devoid of jurisprudential reasoning.

The Nigerian Judiciary and the Courts have had opportunity to decide on the conflict of development and the environment. A concise analysis of some selected cases exposes the jurisprudential persuasion and the techniques developed over time. A good starting point is the case of Shell Petroleum Development Company Nigeria Limited v. Maxon ${ }^{93}$. The Plaintiffs/Respondents suits challenged environmental pollution

${ }^{91}$ Constitution of Nigeria of 1999.

92 S.S Ramphal, Key-Note Address, in: International Commission of Jurist, Development, Human Rights and the Rule of Law, Report of the Conference held in the Hague on 27 April-1 May 1981 and convened by the International Commission of Jurists, 1981, p. 10.

${ }_{93}$ Shell Petroleum Development Company Nigeria Limited v. Maxon (2001) 9 N.W.L.R. pt. 719, 541 - 545 (Nigeria). See also Shell Petroleum Development Company v. H.B. Fisherman (2002) 4 N.W.L.R. pt. 758, 505. 
leading to injurious damage to crops, land, and primary forest due to oil spillage, The Defendants/Appellants Counsel (attorney to the environmental victims) instituted the suit in the State High Court by virtue of the Constitutional provision that:

Subject to the provision of section 251 and other provisions of this constitution, the High Court of a State shall have jurisdiction to hear and determine any civil proceedings in which the existence or extent of a legal right, power, duty, liability, privilege, interest, obligation, or claim is in issue or to hear and determine any penalty or to hear and determine any criminal proceedings involving or relating to any penalty, forfeiture, punishment or other liability in respect of an offence committed by any person. ${ }^{94}$

The defendants objected to the suit by preliminary objection. The High Court upheld the objection on the constitutional ground that a State High Court (which is of close proximity to the environmental victims) does not have jurisdiction to entertain or hear any act or omission connected with and/or pertaining to mines and minerals (including oil fields, oil minerals, geological surveys, and other hydrocarbons-natural gas). This decision was upheld by the Court of Appeal. The excruciating facts of this case made observers wonder whether the philosophy guiding the Nigerian judiciary was devoid of environmental governance principles and only promoting the interest of business concerns. ${ }^{95}$

The Nigerian Supreme Court had a golden opportunity to redress the wrongs in the epoch-making case Shell Petroleum Development Company of Nigeria Limited v. Abel Isaiah" ${ }^{96}$ and others. In 1988 in a village in the Rivers State, a tree fell on a Shell Petroleum Development Company pipeline carrying explicated crude oil from the production well head to a flow station facility. The company employed a contractor to repair the pipeline. In the course of the repairs and in an attempt to re weld or place the damaged portion of the pipeline, noxious and toxic hydrocarbons

94 Section 272 of the Constitution of 1999.

95 B.B Orubebe, Green Economy and Sustainable Development in times of Climate Peril: Prospects and Challenges for Nigeria, "Nigerian Journal of Food, Drug and Health Law" 2014, pp. 47-63.

96 Shell Petroleum Development Company of Nigeria v. Abel Isaiah and others, (1997) 6 N.W.L.R. pt. 508,236 (Nigeria). 
leaked out and spilled on to the respondent's dry land swamps and sensitive wet lands were in the severe damage was caused to the swamp, forests, properties, etc. The respondents maintained unequivocally throughout the course of the case that the company did not construct "oil traps" or take necessary steps to contain damage by the spill. The victims argued consistently that as a result of the oil spillage and owing to the fact that needful precautionary steps were not taken. All the uses to which they put the land, swamps, forest, and streams were permanently destroyed.

The claim was instituted at the Rivers state High Court which in its judgment found for the victims and awarded \#22m damages. Dissatisfied, the company appealed to the Court of Appeal which affirmed the judgment of the lower Court. The Nigerian Supreme Court relied on section 251(i)(n), Federal High Court (Amendment) Decree No. 60 of [1990], section 7(b), 7(3) and 7(5) Oil Pipelines Act Cap. 338 Laws of the Federation of Nigeria, [1990] sections 19 and 20 and the Constitution Suspension and Modification) Decree No.107 section 230(1) and (9) to set aside the judgments of the lower Courts on the grounds that the Court had no jurisdiction. Uthman Mohammed, J.S.C., in his lead Judgment stated copiously that:

The holder of an oil pipeline licence has been made responsible under the law to pay compensation to any person whose land (sic) or interest in land or who suffers any damage in connection with the operation of the pipeline. For the foregoing reasons the construction, operation and maintenance oil and oil pipeline by a holder of an oil prospecting licence is an act pertaining to mining operations. It is clear from the pleadings that the spillage and pollution occurred when the appellant was trying to repair the indented pipeline by cutting off the said section and installing a new section. I think it cannot be disputed if I say that installation of Petroleum Mining Operations. Therefore if an incident happens during the transmission of petroleum to the storage tanks it can be explained as having arisen from or connected with or pertaining to mines, and minerals, including oil fields, and oil mining. I therefore agree that the subject matter of the respondent's claim falls within the exclusive jurisdiction of the Federal High Court as is provided under section 230 (1) (a) of the Constitution (Suspension and Modification) Decree No. 107 Similar opinions concerning claims pertaining to oil spillages have been held by the Courts of Appeal in Barry and 2 Ors. v. Obi A. Eric 
and Ors. (1998) 8 N.W.L.R. (Pt. 562) 404 at 416 and The Shell Petroleum Development Company of Nigerian Limited v. Otelemaba Maxon \& Ors. [2001] F.W.L.R. (part 47) 1030 ... it was decided on 20 ${ }^{\text {th }}$ January 2001 by Port Harcourt Division of the Court of Appeal. Once the jurisdiction of a Court to determine a matter has been ousted any further hearing in the matter is indeed null and void because any decision it makes amounts to nothing.

In his concurring judgment, Ogwuegbu, J.S.C. was emphatic on the issue: 103 (a) "I should also say that section 7 (5) of Decree No. 60 of 1991 ousted the jurisdiction conferred on State High Courts and Magistrate Courts under section 19 and 20 of Oil Pipeline Act Cap. 338 Laws of the Federation of Nigerian 1990. As a result, State High Courts and Magistrate Courts have no jurisdiction whatsoever in any matter under section 7 (1) and (2) of Decree No. 60 of 1991." This according to Professor J. Finine Fekumor is what could be referred to as "an atomic bomb on the issue of the jurisdiction of Nigerian state High Courts on environmental governance or oil and gas operation." ${ }^{\prime 7}$

The effect of the preceding apex Court's attitude towards environmental governance and sustainable development appears to have shaped the ensuing denial of access of the people to the Courts on the subject. However, these and other ineffective rule-based remedies have exacerbated the problem of environmental governance or justice in Nigeria. Although there is no imperial data-based theoretical study establishing a nexus between the outcomes of these and related 'environmental and human rights denial cases' to the increased sabotage of oil and gas infrastructure in Nigeria, there is certainly the anxiety that this could push the largely illiterate population into further acts of rebellion or freedom through self-help, with catastrophic effects on the Nigerian State, the Niger Delta indigenous people, and the environment.

Commenting on the overall decadence of the Nigerian legal framework both jurists and judges acknowledge its inadequacy. In the words of Justice Oputa - Justice of the Supreme Court of Nigeria:

Access to the Courts is a necessary adjunct of the Rules of Law and the effectuation of their rights by the citizens. It underlines and emphasizes that

97 J.F. Fekumo, Oil Pollution and the Problems of Compensation in Nigeria, 2001, p. 8. 
Justice should not be the privilege of the few who are rich, but should be accessible to all the citizens of our country. But access to the Courts implies the payment of summons fees, lawyer's fees, and payment for record of proceedings in the case of appeal. All these are far beyond the reach of the poor, who finding justice too expensive gladly resign themselves to the denial of it.

One of the best tests of the efficacy of the fundamental rights provisions of our Constitution should be whether the rights enshrined therein are accorded to the poor. In theory, Nigeria's Constitution in its preamble talks nobly of promoting the good government and welfare of all persons in our country on the principles of freedom, equality, and Justice; but in actual practice, one will notice that it is the powerful, the rich, the dominant, and the elite class that seem to have all the rights, while the only right which is left to the poor, the weak, and the down-trodden seems to be their right to suffer in silence. ${ }^{98}$

Dr. Aguda, the renowned Nigerian jurist, concluded while commenting on the critical nature of the Nigerian legal framework: "what fair hearing can a poor person hope to have when he cannot even boast of a square meal a day, if he is cheated of his right, he would certainly prefer having the matter in the hands of God than risk death to assert an illusionary right to fair hearing of his environmental grievance by the Courts. To think that a very poor person in Nigeria can have a meaningful day in Court in the pursuit of his or her environmental cum human right, real or imaginary is to live in a fool's paradise. ${ }^{99}$

It is further argued that the legal framework in Nigeria under the military and the present civilian regime has not changed. This is because the same environmental governance law and policy that sustained dictatorial military regimes in the past, which denied the majority of the people access to the Courts remain enforced. The situation is further aggravated because, under collaboration agreements between the government and the corporations, the people do not share or benefit from the proceeds of oil and gas exploitation. So they are poor, illiterate, and are in a vicious circle of poverty and misery in the midst of wealth.

98 J.N. Adula, Perspectives on Human Rights; Human Rights and Social Justice In Nigeria: Issues Delima and Opinions, 1991, p. 231.

99 Ibidem, p. 231. 
There also exists the issue of the lack of an independent judiciary, legal aid, and the ability to finance the costs of litigation (even the costs of Court filing fees). The process of judicial enforcement of environmental or related human rights is also saddled with the limitations decreed by law. ${ }^{100}$ In addition to the above is an adversarial trial process system predicated on a colonial evidential rule system. All these affect the ability of indigenous people to seek redress in the Nigerian Courts for environmental justice.

\section{CONCLUSIONS}

It is obvious that strengthening environmental governance including sustainable development is the most secure path for both countries in times of environmental peril. In India these new judge-driven judicial measures have received broad political and public support. In interactions with powerful industrial heavyweights, politicians have been glad to let the judiciary provide leadership in an otherwise hopeless situation. The public and the media have almost always supported and actively encouraged judicial activism in environmental governance. As a result, in some dire situations, development projects have been delayed or even abandoned owing to environmental-related judicial intervention. A major effect of the encouraging trends in the Indian experience has been the growing number of concerned individuals, citizen groups, and non-governmental organizations exerting pressure on state agencies through the Courts. Experience has shown that the Judiciary can and must take a leading role in initiating rule-based judicial techniques capable of strengthening environmental governance, but it is ultimately the responsibility of the entire people and the government to own the environmental governance process.

The Nigerian domestic legal framework for environmental governance needs to be reviewed in accordance with the country's international

${ }^{100}$ Limitation of Actions and Arbitration Law (Laws of Bendel State), Cap. 89 (1976), (Nigeria), applicable in DeltaState. In this law section 4 provides that actions founded on simple contract or tort (including environmental suits) shall not be brought after the expiration of six years from the date on which the cause of action accrued. 
human and environmental law and policy obligations. The judiciary must overhaul itself and the modus operandi in order to come to terms with the expectations of Nigerians, and to catch up with the progress already recorded by the Indian judiciary in the field of improved environmental governance, in this age of climate peril. 
